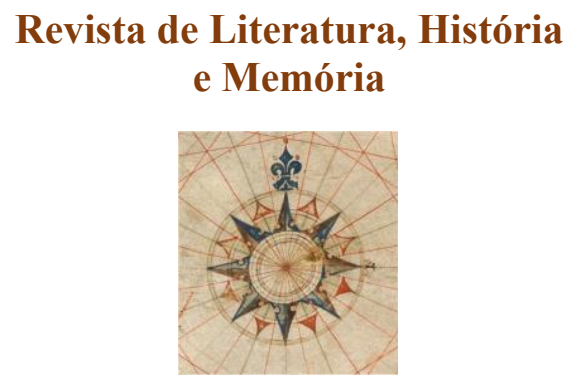

Seção: Pesquisa em Letras no contexto Latino-americano e Literatura, Ensino e Cultura

ISSN 1983-1498

VOL. 17 - No 29 - 2021

U N I O E S T E / CA S C A V E L - p. 175-195

\title{
A MARGINALIDADE LITERÁRIA E O UNDERGROUND EM O CHEIRO DO RALO, DE LOURENÇO MUTARELLI
}

\section{The marginal literature and the underground in $O$ cheiro do ralo of Lourenço Mutarelli}

\author{
Damásio Marques da Silva ${ }^{1}$
}

RESUMO: O objetivo deste artigo foi analisar $O$ Cheiro do Ralo (2002), romance inaugural do cartunista Lourenço Mutarelli, com o propósito de compreender a linguagem underground na estrutura híbrida dentro da forma do gênero romance. Realizou-se a comparação e a análise das diferenças e semelhanças das expressões artística e prosaica de Mutarelli. As teorias selecionadas de Bakhtin sobre o plurilinguismo e o skaz fundamentam a pesquisa a partir do discurso social e o trabalho crítico de Will Eisner (2010) sustenta a entrada da voz do autor através do trabalho artístico, principalmente, na linguagem da graphic novel. As hipóteses afirmam que $O$ Cheiro do Ralo está localizado no limiar do romance e da grafic novel, transitando entre os dois gêneros sem fixar-se em nenhum deles. É conclusivo que $O$ Cheiro do Ralo representa um trabalho mediador de inclusão da literatura underground amparado pela linguagem marginal, que é, por sua vez, evidenciado pelo imaginário artístico. O cartunista converge para a escritura contemporânea em uma linguagem original que "conta e mostra" enquanto imagem e voz social na Literatura Underground.

PALAVRAS-CHAVE: Literatura Underground; Prosa Marginal; Graphic novel; Skaz; Lourenço Mutarelli.

ABSTRACT: The objective of this article was to analyze O Cheiro do Ralo (2002), the inaugural novel by cartoonist Lourenço Mutarelli. The comparison and analysis of the differences and similarities of Mutarelli's artistic and prosaic expressions was carried out. The purpose is to understand the underground language in the hybrid structure within the form of the novel genre. Bakhtin's selected theories on plurilingualism and skaz support research based on social discourse and the critical work of Will Eisner (2010) supports the author's voice through artistic work, mainly in the language of the graphic novel The hypotheses state that $\mathrm{O}$ Cheiro do Ralo is located on the threshold of the romance and the graphic novel, moving between the two genres without fixing on either of them. It is conclusive that $\mathrm{O}$ Cheiro do Ralo represents a mediating work for the inclusion of underground literature supported by marginal language, which is, in turn, evidenced by the artistic imagination. The cartoonist converges to contemporary writing in an original language that "tells and shows" as an image and social voice in Underground Literature.

KEYWORDS: Underground Literature; Marginal prose; Graphic novel; Skaz; Lourenço Mutarelli.

\section{INTRODUÇÃO}

O propósito central deste artigo é o estudo do romance de estreia de Lourenço Mutarelli (1964) - O Cheiro do Ralo - associado à literatura marginal por meio de sua

\footnotetext{
${ }^{1}$ Mestre e Doutorando em Literatura e Crítica Literária pela Pontifícia Universidade Católica de São Paulo (PUC/SP).
} 
linguagem underground. $\mathrm{O}$ termo marginal associado à literatura não é desconhecido. Fora do Brasil, ele já aparece diretamente ligado a produções que datam desde o período do Romantismo. Em nosso país, a expressão serve para designar diversos tipos de produção. Para Oliveira (2011, p.33), “O aspecto característico da literatura marginal contemporânea é o fato de ser produzida por autores da periferia, trazendo novas visões, a partir de um olhar interno, sobre a experiência de viver na condição de marginalizados sociais e culturais".

$\mathrm{Na}$ visão de Oliveira, marginal é a literatura produzida por autores das periferias que têm suas realidades retratadas nessas obras. O termo foi tomado por Ferréz (pseudônimo de Reginaldo Ferreira da Silva), autor de Capão Pecado (1999), Manual Prático do Ódio (2003), e Ninguém é inocente em São Paulo (2006), para denominar a sua produção e a de seguidores desse estilo e frequentadores dos saraus periféricos urbanos. Em texto de abertura da coletânea Literatura marginal: talentos da escrita periférica (2005), Ferréz declara que é "Literatura de rua com sentido sim, com um princípio sim, e com um ideal sim, trazer melhoras para o povo que constrói esse país, mas não recebe sua parte" (Ferréz). Essa modalidade de literatura - marcada por uma linguagem própria, característica da cultura dos excluídos - vem, segundo Ferréz, para suprir uma necessidade, para preencher uma lacuna deixada pelo mercado editorial que não costuma lançar obras de autores da periferia.

Em sua maioria, as leituras realizadas da literatura marginal dão conta de um fator marginal associado à condição de vida de seus produtores e sua situação periférica nos grandes centros urbanos. Parte destes estudos tem origem nos programas de pós-graduação em Sociologia ou Antropologia Social. Nessa perspectiva, as análises centram-se em fatores extraliterários, focados mais na situação dos autores e como estes se fazem representar em suas próprias obras. A literatura de Lourenço Mutarelli, sua marginalização se dá não pela condição marginalizada do produtor, mas pela exclusão causada pelo "mal-estar" próprio da estética underground.

Nosso objetivo maior, neste estudo, é tentar a análise de fenômenos marginais aplicados à obra de Mutarelli, em seu romance de estreia, O Cheiro do Ralo, de 2002. Esse caráter marginal do qual tratamos está ligado ao underground, o marginal que se localiza na margem inferior. Quando citamos, aqui, o termo marginal, falamos em relação à posição central da literatura oficial, canônica. Racionero (2002) esclarece que o underground é um movimento à margem, que nunca aparece como obra oficial e representa as artes ligadas à contracultura como a ênfase na música rock, nas drogas psicodélicas e nas filosofias orientais. É da margem inferior que o underground vê a cultura oficial.

A prosa de Mutarelli, em $O$ Cheiro do Ralo, será analisada a partir de um ponto de 
vista artístico de escrita marginal associada ao popular. A estética underground utiliza a linguagem popular, das ruas e dos quadrinhos, que veicula não o belo, o sublime, mas o grotesco. A inter-relação entre o quadrinista e o escritor Lourenço Mutarelli terá como apoio bibliográfico a obra crítica de Eisner (2010), que chama a atenção para a evolução na arte dos quadrinhos, que passou de uma simples produção para consumo do público infantil a uma arte mais voltada para o público adulto, a partir das graphic novels.

\section{PLANO DA REPRESENTAÇÃO DA CONTRACOMUNICAÇÃO EM O CHEIRO DO $R A L O$}

$O$ Cheiro do Ralo narra o cotidiano de um dono de uma loja de antiguidades, transtornado com o cheiro do esgoto exalado pelo ralo do banheirinho de seu escritório. Esse narrador-personagem transita entre seu trabalho, sua casa e a lanchonete, onde conhece uma balconista e adquire sua grande obsessão. Este ciclo - representado pela repetição dos espaços, somados à sua incessante busca pelos glúteos da garçonete mais o cheiro advindo do ralo - conduz a narrativa.

O próprio Mutarelli o classifica como a "história da busca." A história de $O$ Cheiro do Ralo é contada por meio das relações do protagonista com o outro. Elas vão revelando sua personalidade egocêntrica, fria e desprovida de sentimentos. Todas suas relações são mediadas pelo seu poder de compra. Ele manipula as pessoas que vão a seu estabelecimento para vender alguma coisa com o poder advindo da sua posição, pois é aquele detém o poder, através do dinheiro. Tudo é colocado no plano das coisas, passíveis de serem negociadas, compradas. Até as relações sentimentais, como no caso da ex-noiva, são reificadas. Isso se dá, inclusive, quando tenta literalmente reconstruir o pai por meio de objetos comprados: um olho de vidro, uma perna mecânica, vão construindo a imagem de seu "pai frankenstein."

Nesse jogo de compra e venda, só perde o controle da situação quando alguém utiliza seu próprio método. Uma cliente, por quem - diz ele - começara a sentir alguma coisa, quando lhe oferece o corpo, o faz em troca de dinheiro e aí é ela quem o manipula utilizando os mesmos meios outrora por ele utilizados.

O primeiro romance de Lourenço Mutarelli traz para a prosa uma contaminação da linguagem de quadrinista do autor. Até a publicação do romance, Mutarelli havia produzido apenas quadrinhos, com destaque para as graphic novels. Em entrevista ao Universo HQ (SILVA, 2009), Mutarelli admite a inspiração em amigos próprios para a criação de personagens e na própria vida para o desenvolvimento dos temas de suas produções. $\mathrm{O}$ 
sofrimento com uma síndrome do pânico o levou a tomar vários medicamentos e o fato se refletiu em sua obra.

É marca da prosa romanesca a presença do autor, ainda que de forma dissimulada, por trás da palavra do narrador ou da personagem. As intenções do autor são realizadas por meio da narração ou da fala da personagem revelando seu pensamento, muitas vezes sob a forma de máximas ou axiomas:

O autor se realiza e realiza seu ponto de vista não só no narrador, no seu discurso e na sua linguagem (que, num grau mais ou menos elevado, são objetivos e evidenciados), mas também no objeto da narração, e também realiza o ponto de vista do narrador. Por trás do relato do narrador nós lemos um segundo, o relato do autor sobre o que narra o narrador, e, além disso, sobre o próprio narrador. Percebemos nitidamente cada momento da narração em dois planos: o plano do narrador, na sua perspectiva expressiva e semântico-objetal, e no plano do autor que fala de modo refratado nessa narração e através dela. Nós adivinhamos os acentos do autor que se encontram tanto no objeto da narração como nela própria e na representação do narrador, que se revela no seu processo. Não perceber esse segundo plano intencionalmente acentuado do autor significa não compreender a obra (BAKHTIN, 1990, p.118-119).

O autor coloca-se como que escondido entre a narração e o discurso da personagem. Ele não quer revelar-se e utiliza dessas duas linguagens para expressar-se, mesmo que indiretamente, através delas.

Ocorre a refração das intenções do autor em todas as formas (no narrador, na personagem) e em diferentes graus, ora maior, ora menor, havendo às vezes até uma fusão dessas vozes. Bakhtin (1990) esclarece que o discurso dos personagens é uma forma de introdução do plurilinguismo utilizada no romance por todos para refratar as intenções do autor, sendo a "segunda linguagem do autor." Para o teórico, “As palavras de um personagem quase sempre exercem influência (às vezes poderosa) sobre as do autor, espalhando nelas palavras alheias...” (BAKHTIN, 1990, p.120).

Em $O$ Cheiro do Ralo, a voz do autor confunde-se com a do personagem-narrador quando a questão da arte frente à técnica produz um juízo de valor da personagem:

É que enquanto você falava, eu fiquei tentando lembrar um único nome de um desenhista técnico. Mas só me veio a mente o nome desses que segundo você, não sabem desenhar. Da Vinci, Michelangelo, Chagall, Rubens, Picasso, Donatello, Rembrandt, Mantegna, Caravaggio, Goya, Bosch...

Você seria capaz de citar apenas o nome de um grande desenhista técnico? Só para me refrescar a memória. 
Claro! Aqui mesmo no Brasil temos o grande Gervásio Moretti. Sem falar no Da Vinci, que fazia o que fazia porque era desenhista técnico também, eu não sou homem de muita cultura. [...] (MUTARELLI, 2002, p.82).

O excerto representa a cena em que um senhor tenta vender um estojo contendo um compasso, segundo ele, instrumento de precisão para desenho técnico e que possui um grande valor. Mutarelli, com formação em Belas Artes e desenhista renomado, transparece nas palavras do personagem-narrador, fundindo suas palavras com a dele no embate sobre o valor do desenho técnico e o artístico.

Por vezes, pode ocorrer também o que Bakhtin (1990) denomina "luta de pontos de vista”, são palavras, expressões de intenções alheias, mas que o autor reflete suas intenções, muitas vezes não se solidarizando com elas. Os juízos de valor atribuídos a certas obras de arte e as visões sobre as convenções sociais são formas da perspectiva de outrem rechaçadas por Mutarelli no discurso do personagem-narrador d'O Cheiro do Ralo:

Ele entra. Era um bicho esquisito o que carregava. Porcelana chinesa. Dinastia de fulano. Não sei se era um dragão ou um gato. Ele mesmo deduziu não haver interesse. Acendi um cigarro.

Quando eu percebi, ela perguntou o que eu achava daquilo. Eu falei que era assim mesmo. Então você acha certo um pai de família fazer uma coisa dessas? O que? Gastar tudo no jogo. Claro que não. (MUTARELLI, 2002, p.12).

O que comumente é tido como objeto de valor pela comunidade apreciadora de obras de arte, como as porcelanas antigas, de determinados períodos importantes, de dinastias chinesas, são ridicularizadas pelo narrador ao ponto de não lhe distinguir a diferença na gravura entre um dragão ou um gato, mostrando o total desinteresse da personagem (autor?) por esse tipo de arte. O protagonista do romance demonstra também total desprezo pelas convenções sociais.

O que sua noiva encara como importante perante a sociedade - sua voz traz esse pensamento padrão, a média, o valor corrente - é totalmente negado pela personagem principal. A voz da noiva traz a visão geral média da sociedade que considera errado um pai de família gastar tudo o que ganha no jogo. Além disso, o protagonista do romance rompe com a noiva exatamente no momento dessa discussão, quando os convites do casamento já estavam na gráfica, o que para a noiva, e a opinião corrente, seria um absurdo. Para o noivo não há o menor problema nisso e age com naturalidade, demonstrando o desprezo do autor às convenções e à opinião corrente. Essa luta de pontos de vista aparece em muitos outros 
momentos do romance, evidenciando a posição contrária do autor à visão média da população.

O discurso do autor nas formas do plurilinguismo pode estar também diluído nos discursos diretos de personagens. São zonas que se formam a partir dos discursos das personagens, por meio de palavras e termos espalhados e da intromissão do discurso do autor por meio de reticências, interrogações ou exclamações em momentos expressivos de outrem. Segundo Bakhtin (1990, p.120), "Essa zona é o raio de ação da voz do personagem, que de uma maneira ou de outra se mistura com a do autor".

De volta a TV. Spock analisa uma esponja do espaço. Talvez seja isso. Não, não pode ser. Lembrava do que o homem disse... Acho que o foi o que levou o violino para vender. Pensei em círculo vicioso. Ele disse que o cheiro era meu. [...] Eu tenho quase certeza absoluta de que o ralo já fedia antes de eu ter descoberto a bunda. Acho que sim. É, não é a bunda que faz o ralo feder. Não é não. E se fosse? (MUTARELLI, 2002, p.39).

No caso, essa zona funde voz do personagem e voz do autor, demonstrando na formação do diálogo interior da personagem a intromissão do autor nas reticências e interrogações nas formas de incertezas, reservas e ironias. O trecho traz uma construção próxima do fluxo do pensamento da personagem organizada na forma do monólogo interior. A forma de transmissão do monólogo interior é hibrida e "a voz do autor pode ter diferentes graus de atividade e pode introduzir no discurso transmitido um segundo acento (irônico, indignado, etc.)" (BAKHTIN, 1990, p.123).

Mas, a partir desse segundo plano, o que quer o autor comunicar? Sua voz refratada na voz da personagem ou do narrador traz que intenções? A narrativa de Mutarelli tenta representar o irrepresentável. A narrativa de Mutarelli tenta representar o homem pósmoderno contemporâneo, que por si só já é um ser problemático. Porém, o protagonista de $O$ Cheiro do Ralo, mais do que isso, é um ser do subterrâneo e sua forma de representação não pode de modo algum seguir um método tradicional, linear e de gênero puro. A começar pela representação do significante, não havendo espaço para especulação linguística de significados. A significação parte da forma e do conteúdo que são juntamente configurados para esse fim, são juntamente decodificados, não havendo prevalência de um sobre o outro.

A matéria mutarelliana em $O$ Cheiro do Ralo só pode ser apresentada em um gênero novo, próprio das experimentações do autor, oriundas da arte dos quadrinhos, onde a economia da palavra escrita é completada pelos desenhos. No romance, permanece a economia linguística, subtrai-se o desenho e tudo o que já foi dito, não precisa ser repetido, o 
leitor preenche com sua memória os espaços deixados pelo autor, as lacunas, as elipses, que existem ou porque não precisam mais repetições ou porque são incomunicáveis. "O que pode ser imitado não é informação principal. [...] O incomunicável é o signovo, a informação original.” (PIGNATARI, 1971, p.9).

Pignatari (1971) chama a atenção para a comunicação centrada na informação por meio do código e do repertório das chamadas classes sociais: "Uma grande capacidade de manipulação do código implica em um repertório mais amplo, em maior teor possibilístico de informação" (PIGNATARI, 1971, p.48). As chamadas classes A e B, com maior repertório, e cujo código predominante é a palavra escrita, ocupam menor faixa de audiência em meios de comunicação como a TV, enquanto as classes menos abastadas, com menor acesso à alfabetização e cultura, ou seja, com menor repertório, ocupam as maiores faixas de audiência.

Pignatari (1971) observa que nas classes de repertório mais amplo, nas elites culturais, as informações em outros códigos, como o cinema, a música, a pintura, necessitam tradução para o código escrito, por meio da crítica ou da história da arte, por exemplo, para adquirirem sentido. No entanto, se os repertórios amplos precisam se definir por meio de um código central, com os repertórios baixos não se dá o mesmo processo. O crítico cita como exemplo a dança, envolvendo três sentidos: audição, tato e visão (no candomblé, no samba), em que o repertório das classes populares é superior ao das elites, tanto no sentido da manipulação do código quanto da criação de linguagem. Portanto, pode ser errônea a visão e o pensamento que atribui à arte de cultura de massas uma arte menor.

$\mathrm{Na}$ fusão da graphic novel com o romance, Mutarelli cria uma nova forma de prosa, um novo romance. O Cheiro do Ralo apresenta-se como uma espécie de graphic novel sem desenhos, onde as elipses, os espaços em branco poderiam ser completados pelas imagens. A narração em primeira pessoa confunde o discurso direto da personagem com a própria narração (discurso direto do autor).

No mundo contemporâneo, fraturado, o ser não pode ser representado linearmente, de forma acabada. Só uma linguagem igualmente inacabada pode tentar representar esse ser problemático em permanente construção.

Agambem (2009) aponta para a necessidade de o contemporâneo ser inatual, só deslocando-se, o contemporâneo pode compreender seu próprio tempo. Daí percebe-se que muitas vezes determinadas obras são mal compreendidas em seu período, sendo somente redescobertas tempos depois.

A obra de Mutarelli caracterizou-se pelo experimentalismo. Desde os quadrinhos 
iniciais, com uma estrutura mais reflexiva e maior utilização de traços grotescos, aos últimos trabalhos mais realistas ou impressionistas. No romance também suas narrativas nunca seguiram o esquema padrão clássico, ora fundindo-os com o gênero dramático ou a intromissão das graphic novels. O experimentalismo é a própria forma da arte na contemporaneidade, idiossincrática, não é privilégio de Mutarelli, mas marca de toda essa geração. "A transmissão passiva de conhecimentos adquiridos é uma falácia: só se conhece verdadeiramente, de modo criativo, mediante seleção crítica. Arte viva de nosso tempo é arte experimental...” (PIGNATARI, 1971, p.114).

A forma de representação da realidade está na forma da obra, na própria linguagem da arte, em que conteúdo e forma se conjugam para configurar o todo significativo. Para Pignatari (1971), é pela linguagem e não pelo discurso que se apreende o real como conteúdo novo comunicável. "A obra de arte verdadeiramente nova e inovadora atua no campo da linguagem criativa e criadora de realidades" (PIGNATARI, 1971, p.114). A linguagem artística comunica por si só, não se especula sobre significados. Na narrativa, o que importa não é o enredo, mas a forma como ele é construído. O interesse não está tanto no que se conta, mas como se conta.

A maneira de ver a literatura pós-moderna contemporânea deve, e já começa a, ser repensada. Trata-se de interpretar não só o significante verbal, mas a forma artística. Pignatari (1971) aponta que o conteúdo continua sendo o objeto de análise da poesia brasileira e não sua estrutura significante. Claro que ao comentar a poesia, o crítico faz referência à linguagem poética, o que se aplica também ao romance e toda a arte literária. A forma é parte do conteúdo, que deve ser digerido ao mesmo tempo em que se toma o contato com a forma. $\mathrm{O}$ todo significativo do romance contemporâneo só encontra sentido na conjugação desses dois planos, que são inseparáveis.

A literatura de Lourenço Mutarelli, representada aqui no romance de estreia, $O$ Cheiro do Ralo, apresenta-se como narrativa limiar entre o popular/grotesco, com a linguagem das ruas, a forma consagrada do romance e as técnicas dos quadrinhos.

As ideias bakhtinianas aqui apresentadas justificam a voz do autor na forma híbrida do romance em sua perspectiva linguística, do discurso, e serve de contraponto à visão de Pignatari, da linguagem, da arte. Em se tratando da introdução da voz do autor, Lourenço Mutarelli, que essencialmente produz a arte dos quadrinhos e esta transparece visivelmente em sua produção na prosa, trata-se muito mais de interpretar a linguagem. Isto é, a arte por si só já seria suficiente para justificar a hibridização de linguagens no experimentalismo da representação mutarelliana. Afinal, arte é representação e seu poder como representação é tal 
que, somente a título de pequena ilustração, citamos Gombrich, que retoma os antigos na explicação de que "a fronteira entre o real e imagem é ainda mais vaga” (2013, p.39). Um artista europeu que pintara a imagem do gado nas paredes de uma caverna em uma aldeia africana irritou os moradores que se perguntavam como iriam viver se levaram-lhes o sustento.

\section{ESTRUTURAS DO ROMANCE: O ESTILO GRAPHIC NOVEL}

$\mathrm{Na}$ perspectiva linguística, a linguagem dissimulada do autor e a de outrem pode ser introduzida no romance por meio do discurso do narrador ou da personagem. Tratando ainda do plurilinguismo e as formas de contaminação do discurso de outrem, Bakhtin destaca acerca do personagem:

A mesma hibridização, a mesma mistura dos acentos, o mesmo apagamento das fronteiras entre o discurso do autor e o de outrem são alcançados graças a outras formas de transmissão dos discursos dos personagens. Com apenas três modelos sintáticos de transmissão (discurso direto, discurso indireto e discurso direto impessoal), com as diferentes combinações desses modelos e, principalmente, com os diversos procedimentos da sua réplica de enquadramento e estratificação por meio do contexto do autor, realiza-se o jogo múltiplo dos discursos, seu entrelaçamento e seu contágio recíproco (BAKHTIN, 1990, p.123).

Bakhtin (1990) esclarece ainda que o personagem tem sua área de influência sobre o autor e ultrapassa os limites do discurso direto, sua relação é dialógica, mas não um diálogo dramático, um diálogo entre autor e personagem que só é possível no romance.

A personagem principal de $O$ Cheiro do Ralo, na parte final da narrativa, ao concretizar sua incessante busca, e ao contemplá-la, comenta:

Relembro do velho Borges. Relembro de um livro que li. Relembro um "The Unending Gift". Lembro que a promessa, só os deuses podem fazer. Assim nos falou o velho mestre, nesse ensaio que relembro. Enquanto ela ainda rebola, dançando um triste iê-iê-iê.

Borges fala de um quadro que um pintor lhe prometera.

Mas, esse tal pintor morre antes de realizar a promessa.

E então Borges, disseca o eterno e a promessa.

Ele diz que o quadro já tinha um lugar pré-fixado, que não ocupou. Borges segue pensando no quadro e no homem perdidos. Borges diz que só os deuses poderiam prometer, porque são imortais.

Depois, reflete, que se o quadro tivesse, com o tempo ele seria algo mais, uma coisa.

Uma vaidade. Mas, sigo Borges, ao não ter, o quadro se torna incessante, ilimitado. 
O quadro que não existe é capaz de qualquer forma ou cor.

E de alguma forma ele existe. Vivo. E continua a viver, e se expandir. Incessante.

Borges conclui que há na promessa algo imortal. (MUTARELLI, 2002, p.136).

No excerto, por meio da narração da personagem em $1^{\mathrm{a}}$. pessoa, é possível perceber o diálogo entre o personagem-narrador e o autor acerca da posse e da perda. A busca da personagem é ideal e, uma vez concretizada, perde seu real interesse e valor, torna-se mais "uma coisa" - nas palavras do próprio narrador. Como tudo que ele tranca na sala ao lado de seu escritório, os glúteos da moça da lanchonete, objeto de desejo do protagonista, sofre o processo de reificação e, uma vez concretizado e alcançado o objetivo da busca perde todo seu sentido. O diálogo entre personagem e autor é perceptível nas declarações acerca do ensaio escrito por Borges. $\mathrm{O}$ autor lança mão de máximas proferidas pelo autor argentino para dialogar com as ideias da personagem sobre as questões da espera e da concretização do desejo. No trecho selecionado é possível "ouvir" o autor argumentando junto com o personagem, através das ideias de Borges, que é melhor não possuir, a ter e perder o sentido.

Acerca do plurilinguismo no romance, Bakhtin (1990) esclarece ainda que ele é "o discurso de outrem na linguagem de outrem, que serve para refratar a expressão das intenções do autor" (BAKHTIN, 1990, p.127). Serve a dois locutores, duas vozes: o personagem que fala e a intenção do autor. Essas duas vozes dialogam internamente, como se se conhecessem. É, no entanto, um diálogo potencial, não pode ser delimitado em estrutura dramática, é elaborado na própria linguagem, está inserido no processo criativo e, obra acabada, apresentase como discurso único.

Uma das formas mais importantes da introdução do plurilinguismo no romance é a intercalação de gêneros. Bakhtin (1990) esclarece que o romance permite a introdução de diferentes gêneros na sua composição, tanto literários (poemas, novelas intercaladas, peças líricas), como extraliterários (retóricos, científicos, religiosos, etc.). Qualquer gênero pode adentrar o romance e muitos já foram introduzidos. Quando incluídos no romance, estes gêneros conservam sua linguagem e estilo.

Bakhtin (1990) acrescenta que há um grupo de gêneros que exerce um importante papel estrutural no romance. As cartas, os relatos de viagem, o diário, a biografia ou a confissão podem determinar a forma do romance. Esses gêneros possuem formas semânticoverbais responsáveis por assimilar os distintos aspectos da realidade.

Lukács (2013) também destaca que o caráter descontínuo da realidade, essa inclusão de elementos alheios à épica e à composição literária torna-se visível no todo do romance. 
Como exemplo, Lukács destaca a forma romântica do romance com todo seu lirismo e pensamento, nas palavras de Schlegel:

\begin{abstract}
A poesia romântica é uma poesia universal progressiva. Sua destinação não é apenas unir novamente todos os gêneros separados da poesia e pôr a poesia em contato com filosofia e retórica. Quer e também deve mesclar, ora fundir poesia e prosa, genialidade e crítica [...] Pois quase não posso conceber um romance que não seja uma mistura de narrativa, canção e outras formas (SCHLEGEL Apud LUKÁCS, 2013, p. 81).
\end{abstract}

A própria forma do romance, por si só já é um aglomerado de outros gêneros. A prosa romanesca não é possível sem a inserção de outros gêneros em seu interior, seja do dramático, na forma dos diálogos, do lírico, nas formas poéticas ou mesmo dos gêneros não-literários, como o filosófico ou o retórico. Os gêneros introduzidos no romance o modificam de tal forma que suas linguagens passam a fazer parte da própria forma, podendo inclusive marcar a própria história e linguagem do romance, como confirma Bakhtin, no romance epistolar, por exemplo. Segundo Bakhtin (1990, p.125), "Todos esses gêneros que entram no romance introduzem nele as suas linguagens e, portanto, estratificam a sua unidade linguística e aprofundam de um modo novo o seu plurilinguismo".

A introdução dos diferentes gêneros pode ser ou não intencional. O processo pode ser realizado por meio de uma contaminação não espontânea. No caso de um artista de outra área que se aventura na seara romanesca, como Lourenço Mutarelli, essa contaminação é possível, mesmo que involuntária.

Dessa forma se apresenta o romance de estreia de Mutarelli. Declarando o abandono de suas produções de quadrinhos - que retomaria mais tarde -, o autor, mesmo sem intenção, reproduz na prosa o estilo utilizado nas produções anteriores, advindo dos quadrinhos e, mais especificamente, das graphic novels.

A introdução de gêneros - ou sua fusão - no romance, só o faz enriquecer, pois acarreta a inclusão também de suas linguagens, ampliando o horizonte linguístico e literário. Bakhtin (1990) aponta que todas as formas de enquadramento dos gêneros

assinalam a relativização da consciência linguística [...] porque a prosa romanesca é estranha à ideia de uma linguagem única (como linguagem indiscutível e sem reservas), a consciência da prosa deve orquestrar as suas próprias intenções semânticas, ainda que absolutas. (BAKHTIN, 1990, p.127).

Como forma inacabada, que busca representar o homem, o romance deve incorporar 
todas as linguagens possíveis desse ser que representa e, dessa forma, todos os gêneros, com suas linguagens específicas podem adentrar a forma do romance.

Antes de escrever $O$ Cheiro do Ralo, Lourenço Mutarelli havia produzido toda sua obra no meio dos quadrinhos. Inicialmente em revistas, em conjunto com outros artistas e, posteriormente, na produção de graphic novels, quando ganhou diversos prêmios no meio. A linguagem dos quadrinhos é marcada pelo uso dos recursos visuais e linguísticos. O uso de determinadas imagens e símbolos utilizados repetidas vezes colabora com a ideia de linguagem dos quadrinhos. O leitor da HQ ao se deparar com determinada imagem ou símbolo amplamente utilizado nesse gênero reconhece em sua estrutura o estilo narrativo próprio do gênero. Oliveira (2008) reforça a ideia de interdependência de linguagens na arte dos quadrinhos:

As HQs revelam em sua constituição, uma linguagem intersignica que se dá através de co-relações, co-referências, analogias, e muitas outras possibilidades interativas. A presença ou não de cores, o tipo de traço, o tamanho das figuras, a disposição da linguagem verbal nos balões (ou a ausência deles), a alternância entre a luz e as sombras, e muitos outros recursos são utilizados na composição dos quadrinhos, que se configuram como um mix de diferentes linguagens e recursos compositivos (OLIVEIRA, 2008, p.45).

Para Eisner (2010, p.2), “os processos psicológicos envolvidos na compreensão de uma palavra e uma imagem são análogos, uma vez que a estrutura da ilustração e da prosa são similares." Em boa parte das HQs, a menor unidade narrativa é o quadrinho, em que a linguagem verbal associa-se a linguagem não-verbal para fornecer um significado. A predominância de uma linguagem sobre a outra pode depender de fatores como a mensagem, o estilo, o autor, podendo-se encontrar quadros em que haja somente o texto escrito ou somente a ilustração, sem prejuízo para o entendimento do texto. Como os processos para compreensão dos dois tipos de linguagem - ilustração e prosa - são iguais, não há hierarquia de importância de uma linguagem sobre a outra. A ilustração é parte da narrativa, seja na forma dos desenhos das letras (letreiramento), seja na caracterização e representação das personagens, espaços, cenários. Apesar de toda a junção de linguagem verbal e não-verbal, o quadrinho é essencialmente visual.

A principal diferenciação entre a graphic novel e as revistas de quadrinhos está na extensão da obra. As tiras publicadas em jornais são a origem moderna de toda forma de quadrinhos. Sua extensão é de, geralmente, três quadros e de duração muito curta, veiculam comumente pequenas anedotas. Já as revistas em quadrinhos trazem pequenas histórias, de 
um mesmo autor ou de vários. O público-alvo dessas produções era, na maior parte, o infantil. Hoje, esse público já é bastante diversificado, com predominância, inclusive, do público adulto, que começou a ler quadrinhos ainda na infância e continua nos tempos atuais.

$O$ Cheiro do Ralo utiliza ainda uma linguagem muito presa a das graphic novels do autor. Como se fosse uma graphic novel sem as imagens. No processo narrativo dos quadrinhos, os desenhos fornecem uma imagem possível de ser criada pelo leitor de um texto integralmente verbal. No caso do romance de Mutarelli, a ausência da imagem dos quadros faz com que essa imagem seja completada pelo leitor que, no caso dos quadrinhos, é papel do artista. Ele completa a visão do leitor com a imagem, o que não elimina outras imagens que o leitor possa criar mentalmente. Conforme esclarece Eisner (2010, p.165) "na história em quadrinhos, os desenhos são visuais [...] Um visual substitui o texto; uma ilustração apenas repete, amplia ou estabelece um clima para o tom emocional". Entendemos, entretanto que, diferentemente da ideia de Eisner, o desenho nos quadrinhos não substitui o verbal, mas junto com ele, compõe a linguagem da HQ.

$\mathrm{Na}$ introdução da voz do autor, no conjunto com a voz do personagem e o diálogo produzido entre ambos, transparece uma bivocalidade em que suas vozes não são delimitadas como num diálogo dramático, mas estão juntas e refletem as intenções do autor - mesmo que involuntariamente. Assim, na introdução da linguagem genérica da graphic novel, Mutarelli transparece na voz do narrador personagem de $O$ Cheiro do Ralo, não só no diálogo intrínseco da voz do narrador-personagem, mas na própria fusão do gênero da graphic novel no romance.

Segundo Bakhtin (1990), se o autor não souber utilizar-se dessa bivocalidade, se não tem consciência da relativização linguística do romance e do estilo linguístico da prosa, este não pode criar um romance, com os problemas reais do gênero. Não obstante, sem o plurilinguismo da linguagem, pode criar algo que se assemelha a um romance, mas transforma-se em drama, apenas com rubricas ou indicações cênicas. Certamente não é o que acontece com $O$ Cheiro do Ralo, as linguagens de Mutarelli são introduzidas no romance como forma de enriquecimento na construção da narrativa, trazendo elementos das graphic novels como a concisão narrativa e elíptica e mais a linguagem das ruas em sua perspectiva underground apresentando um universo de distintas linguagens que fazem de sua estreia na prosa um exemplar do gênero romance, na simples acepção do termo.

De forma que, na tradução da ideia de Mutarelli, $O$ Cheiro do Ralo talvez não coubesse nos limites do formato da graphic novel, pois, pensando no papel do leitor, este deveria ter uma maior participação na construção da narrativa. Conforme esclarece Eisner: 
“existe uma espécie de privacidade que um leitor de prosa tradicional desfruta ao traduzir mentalmente um texto descritivo em imagem visual. Trata-se de algo muito pessoal, que permite um envolvimento muito mais participativo do que um voyerismo de examinar uma figura" (EISNER, 2010, 148).

\section{A HISTÓRIA GRÁFICA NA NARRATIVA: AÇÃO, RITMO E TIMING}

A divisão da história em quadros é um expediente utilizado também na construção da estrutura em $O$ Cheiro do Ralo. Dentro dos capítulos, divisões em cenas separadas por travessões exercem o papel dos quadros ou episódios. 
Aí então já não sinto mais nada.

Nada tem para me dar.

Ela chora e bate na minha cara.

Depois chora baixinho, fazendo aquela cara engraçada.

Vou ao banheirinho me limpar e quando volto a encontro no chão.

"A chorar, a chorar, a chorar".

Com os convites na gráfica.

É o que ouço quando ela sai.

Ele entra.

Desculpe amigo, está na minha hora de almoço. Quem te deixou entrar? Foi a mocinha. A mocinha vai ter que arrumar um outro emprego. Aí é a mocinha quem vai chorar.

Na pressa me esqueço do livro.

Antes de entrar me parece que a dona bunda já me esperava. Ansiosa. Ué, hoje não trouxe livro?

Hoje não.

Vai querer o x-calabresa ou o bacon?

Escolhe para mim. Hoje vai ser o que você quiser.

Ela quase riu.

Ela usava uma saia estufada que ocultava seu único dom.

Hoje não é o meu dia.

Nem o meu, retrucou.

Trouxe o x-calabresa.

Acabei pedindo um suco.

Ele entrou. Nem vi o que trazia nas mãos. Aleguei não haver interesse. Ele se contentou em dizer, que cheiro!

É do ralo.

O cheiro vem do ralo do banheirinho.

Ele sai.

Me sinto cansado. Cansado como nunca me senti. Esse cheiro não é meu.

Figura 1 - reprodução de página de $O$ Cheiro do Ralo (MUTARELLI, 2002, p.20). 
Tal qual a divisão em quadros, as cenas ou episódios são separados em $O$ Cheiro do Ralo por travessões. Cenas que caberiam perfeitamente dentro de um quadro. No caso dos quadros, a imagem elimina a necessidade de grandes narrações ou descrições do ambiente. Dessa forma, algumas pequenas descrições e narrações presentes na página retirada de $O$ Cheiro do Ralo, poderiam ser representadas por meio das imagens e as falas transformadas em balões.

O quadrinho tenta lidar com os elementos mais amplos do diálogo: a capacidade decodificadora cognitiva e visual. O artista, para ser bemsucedido nesse nível não verbal, deve levar em consideração o compartilhamento da experiência humana e o fenômeno da percepção que temos dela, que parece consistir em quadrinhos ou episódios (EISNER, 2010, p.39).

No caso das marcas gráficas como o travessão ou o espaço deixado entre as cenas, elas dão ao leitor a dimensão dessa divisão demarcando a duração da ação. É a semelhança na estruturação da graphic novel que fornece agilidade à leitura do romance. Os elementos de percepção de tempo criam o timing próprio das HQs determinando o ritmo de leitura.

O timing utiliza os elementos do tempo para passar uma mensagem. Assim, essa mensagem possui significação específica dentro de determinado tempo, que uma vez alterado, sofre modificação também a mensagem, de forma que o timing deve ser parte integrante e inseparável da própria mensagem, conforme esclarece Eisner:

No cerne do uso sequencial de imagens com o intuito de expressar a passagem do tempo está o caráter compartilhado da sua percepção. Mas para expressar o timing, que é o uso dos elementos do tempo para a obtenção de uma mensagem ou emoção específica, a disposição dos quadrinhos passa a ser elemento fundamental (EISNER, 2010, p.24).

Assim, como na declaração de Eisner, a disposição dos quadros é essencial para a obtenção do ritmo de leitura determinado pelo timing dos quadrinhos, também é fundamental a divisão em cenas de $O$ Cheiro do Ralo, exercendo o papel dos quadros das graphic novels. Essa divisão é um elemento responsável pela nossa percepção da passagem do tempo, assim como o requadro, de tal forma que poderíamos delimitar algumas dessas cenas dentro de um quadro.

O número e o tamanho dos quadrinhos também contribuem para o efeito da passagem de tempo, de forma que um maior número de quadrinhos representa uma ação mais segmentada. Análogo aos quadrinhos, em $O$ Cheiro do Ralo, cenas maiores requerem espaços 
maiores, ao passo que as rápidas passagens são representadas em espaços reduzidos de ação, separados pelos travessões - indicando a rápida passagem de tempo. O tamanho dos quadros, como instrumento de marca de tempo, se assemelha às cenas maiores nas divisões dos capítulos do romance.

Ressaltamos que o timing é o maior responsável pelo ritmo da leitura nos quadrinhos e é ele que proporciona o ritmo ágil de leitura de quadrinhos ao romance de Mutarelli. "Nas histórias em quadrinhos, o timing e o ritmo, elementos criados por meio da ação e do enquadramento, se entrelaçam" (EISNER, 2010, p.30).

O espaço entre as cenas de $O$ Cheiro do Ralo e dos quadros, nas graphic novels, é utilizado para a reflexão e completude do leitor. Segundo McCloud (2005, p.67) "os quadros das histórias fragmentam o tempo e o espaço, oferecendo um ritmo recortado de momentos dissociados. Mas a conclusão permite conectar esses momentos e concluir mentalmente uma unidade contínua e unificada".

$\mathrm{Na}$ ideia de McCloud, a conclusão é a participação do leitor no âmbito das conexões entre os quadros, é o preenchimento de informações pelas quais o leitor é o responsável. Essa conclusão deve acontecer no espaço entre um quadro e outro, chamado de sarjeta. É na sarjeta que a imaginação pode dar sentido a dois quadros, "capta duas imagens distintas e as transforma em uma única ideia” (McCLOUD, 2005, p.66).

\title{
A NARRATIVA DO SKAZ NA VOZ DE OUTREM OU UNDERGROUND
}

O skaz, inicialmente investigado pelos formalistas russos, tem sido constantemente estudado e redefinido. O skaz é "a percepção roteirizada de que o narrador não detém o controle da obra e de que ela está sendo criada 'em processo' e sem revisões" (MORSON; EMERSON, 2008, p.169). Em $O$ Cheiro do Ralo essa percepção é reforçada pelo uso do tempo presente na ação, como se realmente ela estivesse acontecendo no ato da escrita:

\author{
Ela entra chorando. \\ Me pede perdão. \\ Diz que me ama. \\ Diz que não vai me perder assim tão fácil. \\ Me abraça. Eu, imóvel. Digo que ela não tem nada a me oferecer. \\ Ela bate na minha cara.
}

(MUTARELLI, 2002, p.13).

Reforça a ideia de performance, de criação em processo, o caráter oral do skaz: 
A segunda e realmente importante característica do skaz é que o fio narrativo é oral. Ela se orienta para as idiossincrasias do discurso oral, de preferência em dialeto. No skaz, segundo os formalistas, quanto mais idiossincrático, quanto mais acentuadamente oral, tanto melhor (MORSON; EMERSON, 2008, p.169).

A linguagem de $O$ Cheiro do Ralo é constituída de um dialeto oral próprio do underground. Um coloquialismo simples e comum, das ruas:

$[\ldots]$

Ela bateu na minha cara.

Ninguém bate na cara de um homem. Meu pai costumava dizer.

Você está louco?

Claro que não. E a prova disso é que eu vou acabar com essa merda toda.

Você falou que o nosso relacionamento é uma merda.

[...]

Eu ri. Sai daqui! Você é louco! Agora sou eu quem não quer casar com um louco. Ter uns filhos tudo loucos. Sai. E não apareça nunca mais! Seu louco (MUTARELLI, 2002, p. 12 - grifos do autor).

O uso de expressões chulas e o problema da concordância evidenciam as marcas da oralidade. Além disso, $O$ Cheiro do Ralo traz na voz da personagem a introdução da voz do autor, um artista produtor de quadrinhos underground. E é justamente essa uma das principais características do skaz. No skaz o discurso deve ser bivocalizado. Morson \& Emerson (2008, p.169) consideram que "os exemplos mais interessantes de skaz são bivocalizados":

Ignorar no skaz sua orientação para o discurso de um outro e, consequentemente, sua bivocalização, é negar a si mesmo qualquer compreensão daquelas complexas inter-relações nas quais as vozes, uma vez tornadas varidirecionais, podem entrar nos limites do discurso do skaz (BAKHTIN apud MORSON; EMERSON, 2008, p.169).

É a partir das falas das personagens que o autor se faz presente, ele está no discurso, através das palavras do narrador ou das personagens, nunca dele mesmo:

[...] o discurso do narrador nunca pode ser puramente objetificado, nem mesmo quando ele é um dos heróis e assume apenas uma parte da narração. Nessa narração, pois, importa ao autor não só a maneira individual e típica de pensar, viver, falar, mas acima de tudo a maneira de ver e representar: nisto reside sua função direta como narrador, substituto do autor. Por isso a atitude do autor, como ocorre na estilização, penetra-lhe no âmago do discurso, convencionando-o em maior ou menor grau. $\mathrm{O}$ autor não nos mostra a palavra dele (como palavra objetificada do herói) mas a usa de dentro para fora para atender aos seus fins, forçando-nos a sentir nitidamente a distância entre ele, autor, e a palavra do outro (BAKHTIN, 2005, pp. 190/191). 
Em um discurso bivocal é possível verificar uma refração da ideia do autor na fala do narrador:

Paul Auster me deixa confuso. Ele escreve no ritmo que penso. Vertiginoso. Todos aqueles Sr. White, Sr. Green. Como no jogo do tabuleiro.

Sr. White, com a faca na biblioteca.

"Da mão para a boca".

(MUTARELLI, 2002, p.13).

Bakhtin (2005) cita Eikhenbaum como o primeiro a levantar o problema do skaz, no entanto, ele o compreendia apenas como forma verbal de narrativa, discurso falado. Bakhtin complementa que o skaz é "acima de tudo uma orientação voltada para o discurso do outro e, consequentemente, para o discurso falado" (BAKHTIN, 2005, p. 192).

Por possuir $O$ Cheiro do Ralo uma narração em $1^{\text {a }}$. pessoa poderia o processo ser diferenciado? Poder-se-ia pensar que uma narração em primeira pessoa seria distinta no tratamento do skaz, afinal narrador e personagem apresentam-se como uma só voz. Observamos o skaz no romance de Mutarelli, tanto no que diz respeito à oralidade quanto no diálogo com a voz do outro, a introdução da voz do autor. Destacamos as palavras de Neres (2009, p.8), “Como falamos em linguagem e literatura é essencialmente linguagem, não podemos desconsiderar que é exatamente pela linguagem que o autor se aproxima do seu texto...” A linguagem do autor transparece em seu texto seja pela bivocalização do discurso língua - ou pela introdução da arte, no caso de Mutarelli, a voz do autor é a arte underground.

\section{CONSIDERAÇÕES FINAIS}

Como pudemos observar, o romance de estreia de Mutarelli traz em toda sua hibridização de linguagens a ideia da contracomunicação. O romance comunica, mas por vias distintas das tradicionais, por meio da forma, do significante e das vizinhanças, não do significado.

A literatura underground encontra em Mutarelli uma inovação na forma do romance com base na estrutura da graphic novel. Podemos verificar que a linguagem de $O$ Cheiro do Ralo situa-se em um não-lugar, no limiar do romance e da graphic novel, transitando entre os dois gêneros. É essa fusão dos gêneros que possibilita ainda a entrada de outras linguagens artísticas, como a música, o cinema ou a estética grotesca, via a obra de Bosch.

A escrita underground utiliza-se de procedimentos artísticos das mais diferentes áreas para formar a sua expressão estética. $\mathrm{O}$ underground localiza-se na margem inferior da cultura 
oficial e é de lá que a enxerga, do subsolo, daí a necessidade de rebaixar e reaproveitar a arte oficial canônica, para ressignificá-la.

A arte underground deseja ser central, porém, com sua própria linguagem, a dos quadrinhos, o reaproveitamento de outras estéticas e culturas, a linguagem das ruas. Não aceita concessões, não pretende se adequar ao cânone, quer levar sua linguagem marginal às artes oficiais.

Tal qual no mundo de Rabelais, a linguagem popular não quer alcançar somente o povo, mas a elite literária e, ainda como no autor francês, em Mutarelli a mistura de estilos, estéticas e linguagens, as histórias cotidianas mesclam cultura de massas e reflexões filosófico-existenciais.

$\mathrm{Na}$ linguagem underground de $O$ Cheiro do Ralo prevalece a linguagem artística, principalmente, dos quadrinhos, dos quais seu autor foi um dos principais realizadores no Brasil. Eisner aponta para o processo de leitura dos quadrinhos, que deve ser enxergado essencialmente como uma arte narrativa e não, como erroneamente se coloca, parte da literatura.

Em $O$ Cheiro do Ralo é a forma narrativa própria da graphic novel que adentra a literatura, na forma do romance. Nos quadrinhos underground predominam os traços grosseiros e, tanto nos HQs quanto na literatura, a linguagem chula permeada de palavrões e coloquialismos próprios da oralidade são marcas desse estilo. Nesse sentido, o skaz também desempenha um importante papel, pois é o responsável, na visão do discurso social, pela entrada dessa oralidade, no diálogo com a voz do autor, na forma do romance.

\section{REFERÊNCIAS}

AGAMBEN, Giorgio. O que é o contemporâneo?: e outros ensaios. Chapecó: Argos, 2009.

BAKHTIN, Mikhail Mikhailovitch. Questões de literatura e de estética. São Paulo: Hucitec, 1990.

Universitária, 2005.

. Problemas da Poética de Dostoiévski. Rio de Janeiro: Editora Forense

EISNER, Will. Quadrinhos e arte sequencial: princípios e práticas do lendário cartunista. São Paulo: Editora WMF Martins Fontes, 2010.

FÉRREZ. Prefácio. In: Literatura marginal: talentos da escrita periférica. Disponível em:< http://revistaepoca.globo.com/Revista/Epoca/0,,EDR71411-5856,00.html > Acesso em $12 / 11 / 2013$. 
GOMBRICH, E. H. A história da Arte. Rio de Janeiro: LTC, 2013.

LUKÁCS, Georg. A teoria do romance. São Paulo: Duas Cidades; Ed 34, 2013.

MCCLOUD, Scott. Desvendando os quadrinhos. São Paulo: M.Books do Brasil Editora, 2005.

MORSON, Gary Saul; EMERSON, Caryl. Mikhail Bakhtin: criação de uma prosaística. São Paulo: Editora da Universidade de São Paulo, 2008.

MUTARELLI, Lourenço. O Cheiro do Ralo. São Paulo: Devir, 2002.

NERES. Jorge Paulo de Oliveira. O skaz enquanto instrumento de trapaça: uma leitura de Delibes e de Assis Brasil. Disponível em: https://www.yumpu.com/pt/document/view/12920744/o-skaz-enquanto-instrumento-detrapaca-uma-leitura-revista-icarahy Acesso em: 23/08/2014.

OLIVEIRA, Maria Cristina Xavier de. A arte dos quadrinhos e o literário - a contribuição do diálogo entre o verbal e o visual para a reprodução e inovação dos modelos clássicos da cultura. 2008. Tese de doutorado da Universidade de São Paulo. Disponível em: < http://www.teses.usp.br/teses/disponiveis/8/8156/tde-30012009-154912/pt-br.php $>$ Acesso em: 24/04/2014.

OLIVEIRA, Rejane Pivetta de. Literatura marginal: questionamentos à teoria literária. IN: Ipotesi, Juiz de Fora, v.15, n.2 - Especial, p. 31-39, jul/dez. 2011. Disponível em: < http://www.ufjf.br/revistaipotesi/files/2011/05/7-Literatura.pdf-> Acesso em 03/03/2013.

PIGNATARI, Décio. Contracomunicação. São Paulo: Editora Perspectiva, 1971.

RACIONERO, Luis. Filosofías del underground. Barcelona: Anagrama, 2002.

SILVA, Carla Cardoso. O eu confessional nos quadrinhos: apontamentos sobre a obra em quadrinhos Mundo Pet, de Lourenço Mutarelli, sob a perspectiva do "pacto autobiográfíco" de Philippe Lejeune. 2Disponível em: http://www.essentiaeditora.iff.edu.br/index.php/enletrarte/article/view/1754 Acesso em 17 de novembro de 2013. 